\title{
Geography education research in Indonesia: retrospect and prospect
}

\section{Dwi Angga Oktavianto*}

* SMK Negeri 1 Binuang, South Kalimantan, Indonesia

\section{ARTICLES INFO}

Profil Articles:

Sent: $19-10-2019$

Approved: 6-12-2019

Published: $30-1-2020$

\section{Key words:}

geography education research; development of geography education; geography educator

\section{ABSTRACT}

Geography Education Research has been part of the Geography Development in Indonesia. So far there has been no research on the condition of Geography Education Research in Indonesia. This study aims to identify the development of Geography by using qualitative research methods. Study literature is done by explores articles about Geography Education Research that sourced from journals produced by departments or faculties of Geography in Indonesia and have been indexed by SINTA. The results is that the most research in 1980's with observation and writing narratives, concerning the condition of geography teaching in schools about teachers, curriculum, textbooks, and students who study geography. Geography education research in 1990s until the 2000s in Indonesia developed poorly due to the lack of interest for geography educators in conducting geography education research. Geography education research in Indonesia developed well in 2010s. The moment of geography education research development in Indonesia needs to be maintained and improved by geography education academics.

This is an open access article under the CC-BY-SA license

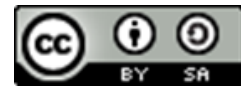

\section{Correspondent Author:}

Dwi Angga Oktavianto

SMK Negeri 1 Binuang

Pualam Sari, Binuang, Tapin Regency, South Kalimantan, Indonesia 71184

E-mail: oktavianto.angga7@gmail.com

\section{INTRODUCTION}

The concern of geography education research in Indonesia is needed. Indonesia has many geography education majors. Based on the National Accreditation Board of Higher Education (BAN-PT), Indonesia has two doctoral degrees, five master degrees, and 47 undergraduate degrees program of Geography Education (BAN-PT, 2018). Whereas for Geography study program there is one doctoral degree, two master degrees, and 10 undergraduate degrees (BAN-PT, 2018). The development of geography education research is expected from many majors in Indonesia. Master students and their geography lecturers are still hesitant and reluctant to conduct geography education research, discuss geography education theory, and publish in particular journals designed for geography education. Roger Firth said that better informed theoretical knowledge and can be able to connect between knowledge, curriculum and pedagogy, so the development of geography education research specifically is needed. However, the geography education research in Indonesia has not been satisfying in quantity and quality.

Geography education research is part of geography research and educational research. Geography education research is a research in geography and in education 
Jurnal Pendidikan Geografi:

Kajian, Teori, dan Praktik dalam Bidang Pendidikan dan Ilmu Geografi

Volume 25, Nomor 1, Jan 2020, Hal 54-60

overlaps 'What is geography learning? What is the nature of geography knowledge? What skills enhance geography learning?'. The condition of geography education research in Indonesia must be a basis for describing what has been done, and then how to develop it in the future. The way to find it out is observing journal which allows it to accommodate findings, ideas or anything about geography education.

The theme of geography education research is so broad. Teaching and learning are the main themes in geography education research. Environmental education is one of interesting theme in geography education research. Textbooks can be used as references to find the quality of geography education. The material of teaching is important in geography learning and must be studied to have high quality of teaching. Learning outcomes are an indicator of succeed in geography learning and need to be studied. Designing, using, and evaluating multimedia learning in geography is very important as part of assessing the effectiveness of learning media. The teacher is one of the main elements in learning georgraphy. Students who are studying geography can lead them to success in geography education. The existence of these themes will make the researchers reference in analyzing geography journal articles to be used as a reference and foundation in geography research development in Indonesia.

Journal as the medium of communication between practitioners of geography education research is very important. Since 2017 the Ministry of Research and Technology of Higher Education builds a database index system for journals in Indonesia, named SINTA. SINTA can be used as a reference to determine the quality of a journal. Journals relating to geography education research to be analyzed by relying on data from SINTA. This study conducted to identify the development of Geography by using qualitative research methods.

\section{METHOD}

This study uses qualitative research method by using literature review. Literature review is done by explores articles about Geography Education Research. Data in this study sourced from journals produced by departments or faculties of Geography in Indonesia and have been indexed by SINTA. This also looks at geography education journals and geography journals published by agencies related to the faculty or geography department and indexed SINTA. Therefore, there are three stages of this research. First, searching for journals in SINTA which are published by geography agencies or geography education based on the ranking of SINTA. Secondly, counting journal documents (articles) related to geography education research. Third, the stage of analysis and interpretation.

The SINTA journal search that contains a lot of journal articles is done by using the keywords; geography education, environmental education, learning, teaching materials, learning outcomes, textbooks, multimedia, teachers, and students. These keywords will be used as a benchmark whether or not the journal articles are included in

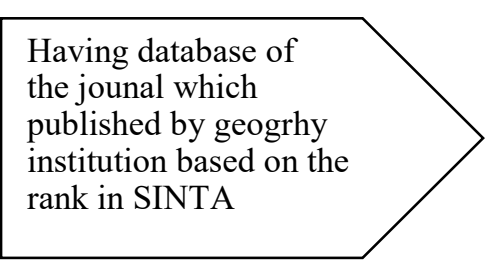

Having database of the jounal which published by geogrhy institution based on the rank in SINTA
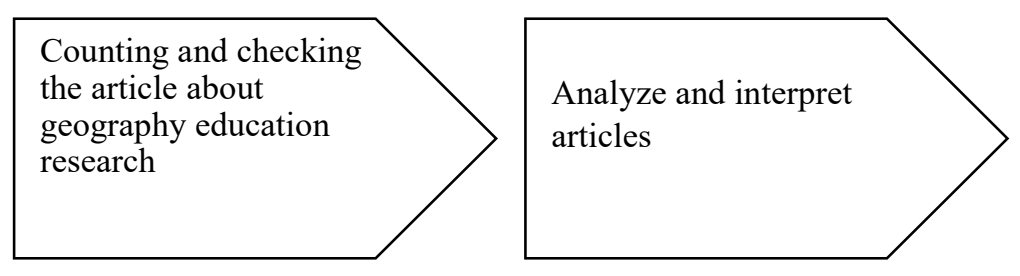

Figure 1. Journal analyses proces 
Jurnal Pendidikan Geografi:

Kajian, Teori, dan Praktik dalam Bidang Pendidikan dan Ilmu Geografi

Volume 25, Nomor 1, Jan 2020, Hal 54-60

Table 1. Journal of Geography that has been indexed by SINTA

\begin{tabular}{|c|c|c|c|}
\hline Index Level & Total & Journal's Name & Institution \\
\hline S1 & 1 & Indonesia Journal of Geography* & Faculty of Geography UGM \\
\hline \multirow[t]{2}{*}{$\mathbf{S 2}$} & 2 & Forum Geografi & Faculty of Geography UMS \\
\hline & & Majalah Geografi Indonesia & Faculty of Geography UGM \\
\hline \multirow[t]{2}{*}{$\mathbf{S 3}$} & 2 & Jurnal Geografi & $\begin{array}{l}\text { Geography Education Major } \\
\text { Faculty of Social Science } \\
\text { Medan State University }\end{array}$ \\
\hline & & Jurnal Pendidikan Geografi & $\begin{array}{c}\text { Geography Education Major } \\
\text { Faculty of Social Science } \\
\text { Malang State University }\end{array}$ \\
\hline \multirow[t]{6}{*}{ S4 } & 4 & Media Komunikasi Geografi & $\begin{array}{l}\text { Faculty of Law and Social Science } \\
\text { Ganesha Education University }\end{array}$ \\
\hline & & Geo-Image & \\
\hline & & & Semarang State University \\
\hline & & Jurnal Geografi : Media Informasi & Geography Major \\
\hline & & $\begin{array}{l}\text { Pengembangan dan Profesi Kege- } \\
\text { ografian }\end{array}$ & $\begin{array}{l}\text { Faculty of Social Science } \\
\text { Semarang State University }\end{array}$ \\
\hline & & $\begin{array}{l}\text { Spatial: Wahana Komunikasi dan } \\
\text { Informasi Geografi }\end{array}$ & $\begin{array}{c}\text { Faculty of Social Science } \\
\text { Jakarta State University }\end{array}$ \\
\hline \multirow[t]{8}{*}{ S5 } & 4 & Jurnal Spasial: Penelitian dan & Gegraphy Education Study Program \\
\hline & & $\begin{array}{c}\text { Terapan Ilmu Geografi serta } \\
\text { Pendidikan Geografi }\end{array}$ & STKIP PGRI West Sumatra \\
\hline & & GeoEco & $\begin{array}{l}\text { PKLH Master Degree Program Sebelas } \\
\text { Maret University }\end{array}$ \\
\hline & & Jurnal Tunas Geografi & Geography Education Major \\
\hline & & & $\begin{array}{l}\text { Faculty of Social Science } \\
\text { Medan State University }\end{array}$ \\
\hline & & Edu Geography & Geography Major \\
\hline & & & Faculty of Social Science \\
\hline & & & Semarang State University \\
\hline
\end{tabular}

Source: http://sinta2.ristekdikti.go.id/ (Accessed by the Author in February 2019)

Table 2. Number of Geography Education Research Articles in Indonesia based on data of SINTA

\begin{tabular}{cccc}
\hline $\begin{array}{c}\text { The Level of Index } \\
\text { SINTA }\end{array}$ & $\begin{array}{c}\text { The Number of } \\
\text { Research } \\
\text { Articles }\end{array}$ & $\begin{array}{c}\text { The Number of Articles about } \\
\text { Geography Education }\end{array}$ & Percentage (\%) \\
\hline S1 & 479 & 3 & 0,63 \\
S2 & 1056 & 7 & 0,66 \\
S3 & 318 & 76 & 23,53 \\
S4* & 200 & 35 & 17,5 \\
S5** & - & - & - \\
\hline
\end{tabular}

Source: Author Data, 2018 (processed from SINTA data record) 
Jurnal Pendidikan Geografi:

Kajian, Teori, dan Praktik dalam Bidang Pendidikan dan Ilmu Geografi

Volume 25, Nomor 1, Jan 2020, Hal 54-60

geography education research. This is to obtain data of the intensity of geography education research is published in a journal.

\section{RESULT AND DISCUSSIONS}

This study was conducted in February 2019 on the indexed journals of SINTA, a group of geography or geography education, issued by geography or geography education institutions and in which it is possible to include geography education research. The number of geography journals to have in a forum for communication for geography education researchers is only 13 journals that indexed SINTA. As quantity it is so small number compared to the thousands of journals that have been indexed by SINTA. However, on the quality side, the articles published by these journals should be high quality articles. Unfortunately in this study it did not examine the quality of journal articles.

Geography education based on Table 2. is not an interesting field as a theme of geography research in Indonesia. The Indonesian Journal of Geography, which is the only Scopus indexed geography journal in Indonesia, provides less geography education research. SINTA record data shows 3 articles or $0.63 \%$ out of articles about geography education research themes. These three journals have two categories, namely articles on environmental education, two articles and the other about geography education in the village. This implies that the Indonesian Journal of Geography issued by the Faculty of Geography UGM can accommodate geography education studies related to environmental education, based on existing departments in the Faculty named Environmental Geography. This is relevant with Bednarz who states that education about the environment is very interesting to be studied by geographers.

There are two journals that are included in the S2 in SINTA category, the Forum Geografi, which is produced by the Faculty of Geography UMS and the Majalah Geografi published by the Faculty of Geography UGM. Less articles on geography education research were found in these two journals, less than $1 \%$. Articles included in the Forum Geografi journal such as one article about students, one article about learning, and articles about teacher. Meanwhile, in the journal Majalah Geografi found; one article of education, two articles of teaching, one article of students and environment. Based on the data obtained, it can be concluded that geography education studies published in the journal indexed by S2 SINTA index are more diverse than those published on the S1 Index of SINTA.

The three articles are interesting to have further discussion, such as two articles on teaching and one article on education, which were published in the early edition of Majalah Geografi, in 1988 and 1990. These three articles are; Highlighting the Imbalance of Geography Teaching, A View of Geography Study Materials in Pre-Higher Education, and Implementation of Space Science Teaching in High Schools based on the 1984 High School Curriculum. These three articles state geography academics interest or interest in the field of geography education research, especially at high school education. The 1988 article also states the beginning of geography education research in Indonesia.

One of the first edition of Majalah Geografi has the article of Bintarto. We knew that Bintarto is a well-known geography scientist in Indonesia, and he is very interested in geography education. It means geography research was supported by experts. Four years after the official geography entered the school curriculum, the 1984 curriculum, Bintarto stated that the main problem with geography education in high school was the number of textbooks and geography learning. Another thing that he concern with was the need for thinking and improving the geography curriculum. It means geography 
Jurnal Pendidikan Geografi:

Kajian, Teori, dan Praktik dalam Bidang Pendidikan dan Ilmu Geografi

Volume 25, Nomor 1, Jan 2020, Hal 54-60

education that has been evaluated in these four years, and the geography curriculum needs to be reviewed. Curriculum evaluation is also implied, which states that teaching about space stuff must be taught geographically .

The second edition of Majalah Geografi contains an article on geography education. In this edition, initially the geography in the 1984 curriculum became a core subject was separate from social subject. However, unfortunately geography has not been taught since the first grade of high school (now named $10^{\text {th }}$ grade). Other problems in the 1984 curriculum include; the reversal order of the material was delivered, spatial concepts did not emphasize the material, textbooks for high school had not been written by the teacher. From these various problems, the teachers were not sure about to achieve geography learning goals, the purpose of deliver material; to develop critical and creative ways of thinking, form a rational attitude and be responsible for problems that arise as human interactions and nature. On the other hand, a solution was also offered in the article, namely the formation of teacher associations in the term of MGMP (Subject Teacher Conference) geography, geography learning must be done indoors and outdoors, and the need for cooperation between teachers and lecturers in writing textbooks for high school.

The focus of geography education research on Majalah Geografi, although it only consists of three articles is so various and used as a reference for subsequent geography researchers. This is relevant with the opinions of foreign experts who also focus on geography education research, that textbooks, curriculum, teachers, and students are interesting research in geography education research. As a milestone in the development of geography education, in the late 1980s to the early 1990s it was the beginning of geography education research in Indonesia.

Table 1. shows that two journals by geography institutions in SINTA S3 index, namely the Jurnal Pendidikan Geografi published by the Department of Geography of the State University of Malang (UM) and Jurnal Geografi by the Geography Department of Medan State University (Unimed). Nearly 25\% articles that published are articles of geography education research. But it is actually less encouraging. The reason is since it has specific name, namely Jurnal Pendidikan Geografi, but articles in the form of geography education are not dominant. This also confirms that geography education research is not interesting compared to geography research.

The analysis was focused on UM Jurnal Pendidikan Geografi. It is due to the expectation to provide a complete explanation of geography education research. Another consideration is UM as the university that already has a doctoral degree in Geography Education and pioneered the earliest master degree in Geography Education. Based on these reasons the researcher believes that the Jurnal Pendidikan Geografi has complete data on the development of geography education research in Indonesia. Articles related to education first appeared in Jurnal Pendidikan Geografi is the Role of Education in Improving the Quality of Human Resource. The article connects geographical problems such as population growth rates, educational product disparities and the needs of labor in the industry and provides suggestions that education can overcome these problems. Moreover, there are articles related to teaching, with entitle Teaching Social Studies in Australia. This article is the only article written by foreign academics in this journal. Social studies in Australia learn about society and the environment, in Indonesia it is same as geography.

Outdoor geography learning has also been carried out by geography educators in Indonesia. This can be seen in the article entitled The Effect of Outdoor Learning on Knowledge and Attitudes of Environmental Preservation of Bachelor degree program of 
Geography Education Student. Based on this article it can be concluded that the idea of outdoor learning in geography education was delivered by Bintarto. The findings state that outdoor learning fosters an environmentally caring attitude to students.

The education of disaster also being concern for geography education researchers. Landslide Disaster Preparedness Education For Early Childhood Students With Media Based Fairy Tales Method Pop Up Book In Day Care of Dewi Sartika, Bergas District. This study reveal the efficacy of compiling guidance of learning methods by storytelling to day care children with the Pop Up Book model.

Geography education research with experimental research methods, classroom action research (CAR), and research \& development (R \& D) in the 2010 decade until now dominated research with the aim of knowing the effect of a learning model on students' thinking abilities and student skills. The Effect of Project-Based Learning Model on the Ability of Writing Geography Scientific Work High School Students is a study that examines the effect of a learning model on writing skills. Meanwhile, the other studies search about the influence of learning models, among others; review of Trefffinger's learning model on critical and creative thinking skills, the influence of inquiry learning models on learning outcomes, the influence of guided inquiry on combining problem based learning and team games tournament to rise the interest and learning outcomes, Jigsaw on learning outcomes.

The research of $\mathrm{R} \& \mathrm{D}$ produces many books, teaching materials and student worksheets. Development of local wisdom-based teaching material, then digital teaching materials is an interesting geography education research in utilizing technological advances and local knowledge. Development of teaching materials based on the atmosphere, lithosphere, mining materials have also become geography research interest in Indonesia. This is also the acceptance of Bintarto challenge that challenges geography educators to produce quality teaching books or materials.

Research on geography teachers was also part of the 2010's geography education research. Research on teacher readiness in disaster-prone areas is a great research. It provides an illustration of adult educator about their readiness to face disasters. Furthermore, their readiness can be delivered to students. In 2010 the geography education research as great interest to geographical academics in Indonesia has begun.

\section{CONCLUSION}

Geography education research in Indonesia since 1988 proves that geography academics have been interested in geography education research. Most research is observation and writing narratives, concerning the condition of geography teaching in schools about teachers, curriculum, textbooks, and students who study geography. Geography education research in 1990s until the 2000s in Indonesia developed poorly due to the lack of interest for geography educators in conducting geography education research. This might be due to the absence of a master and doctoral degree programs of geography education institution at that time. Moreover, what makes harder for geography education research is geography education lecturers are interest in research about geography than geography education. Geography education research in Indonesia developed well in 2010s. This can be seen from the various theme of geography education research and the various geography research methods used. The disadvantage is the lack of geography education research using qualitative research methods. In addition, there is no particular geography education journal in Indonesia that has international index such as Scopus index. This problem can be a barrier to geography education research since if it is only published in national journals, the development of 
Jurnal Pendidikan Geografi:

Kajian, Teori, dan Praktik dalam Bidang Pendidikan dan Ilmu Geografi

Volume 25, Nomor 1, Jan 2020, Hal 54-60

geography education research is difficult to develop well, because it is limited to national scale only. The basic and communication need to collaborate with foreign geography education experts.

\section{REFERENCES}

Bednarz, S. (2000). Geography education research in the journal of geography 19881997. International Research in Geographical and Environmental Education, 9(2), 128-140.

Bednarz, S. W. (2002). Using action research to implement the national geography standards: Teachers as researchers. Journal of Geography, 101(3), 103-111.

Firth, R., \& Winter, C. (2007). Constructing education for sustainable development: The secondary school geography curriculum and initial teacher training. Environmental Education Research, 13(5), 599-619.

Healey, M. (2005). Linking research and teaching to benefit student learning. Journal of Geography in Higher Education, 29(2), 183-201.

Jones, M., \& Lambert, D. (Eds.). (2013). Debates in geography education. Routledge.

Krygier, J. B., Reeves, C., DiBiase, D., \& Cupp, J. (1997). Design, implementation and evaluation of multimedia resources for geography and earth science education. Journal of Geography in Higher Education, 21(1), 17-39.

Lambert, D. (2010). Geography education research and why it matters. International Research in Geographical and Environmental Education, 19(2), 83-86.

Pain, R., Finn, M., Bouveng, R., \& Ngobe, G. (2013). Productive tensions-engaging geography students in participatory action research with communities. Journal of Geography in Higher Education, 37(1), 28-43. 